\title{
FCER2 Gene
}

National Cancer Institute

\section{Source}

National Cancer Institute. FCER2 Gene. NCI Thesaurus. Code C96899.

This gene is involved in the production of IgE and B cell differentiation. 